\title{
Examination of the role of FSH in periovulatory events in the hamster
}

\author{
C. S. Sheela Rani and N. R. Moudgal \\ Laboratory of Endocrine Biochemistry, Department of Biochemistry, Indian Institute of Science, \\ Bangalore 560012, India
}

\begin{abstract}
Summary. The need for endogenous FSH in the periovulatory events such as oocyte maturation, ovulation, luteinization, maintenance of luteal function and follicular maturation was examined in the cyclic hamster. A specific antiserum to ovine FSH, shown to be free of antibodies to LH and to cross-react with FSH of the hamster, was used to neutralize endogenous FSH at various times. Administration of this antiserum during pro-oestrus did not affect oocyte maturation and ovulation, as judged by the normality of the ova to undergo fertilization and normal implantation. It also had no effect on the process of luteinization or on the maintenance of luteal function, as indicated by the normal levels of plasma and luteal progesterone during pro-oestrus and oestrus during the cycle and in pregnancy. All these processes were, however, disrupted by administration of an antiserum to ovine $\mathrm{LH}$, thereby demonstrating their dependence on endogenous LH.

Although FSH antiserum given at pro-oestrus did not prevent the imminent ovulation, it blocked the ovulation occurring at oestrus of the next cycle. This antiserum was effective in preventing the ensuing ovulation when given at any other time of the cycle until the morning of pro-oestrus. It is concluded that, in the hamster, high levels of FSH during pro-oestrus and oestrus are required for initiating maturation of a new set of follicles which are dependent on the trophic support of FSH throughout the cycle until the morning of pro-oestrus. Such follicles then appear to need only LH for subsequent ovulatory and associated processes.
\end{abstract}

\section{Introduction}

The exact physiological role of FSH in the reproductive processes of the female mammal remains unclear, despite intensive efforts by several investigators. An examination of the secretory pattern of FSH and LH throughout the oestrous or menstrual cycles of most mammals indicates that both these gonadotrophins are secreted in the form of a surge just before ovulation; thereafter the circulating levels return to the basal values found at other times of the cycle. This fact led to the belief that all ovarian processes occurring during the periovulatory period could be dependent on both gonadotrophins. A number of important events are initiated during this period: e.g. resumption of the meiotic division in the oocyte; ovulation; an abrupt increase in the secretion of progesterone and oestrogen, the former perhaps indicating the initiation of luteinization of follicular cells; the initiation of follicular maturation leading to the formation of a new set of mature follicles ready to ovulate at the end of the cycle. It is established that these events are dependent on the presence of pituitary gonadotrophins because hypophysectomy leads to a total arrest of all these functions. Several model systems have been used to examine the relative ability of FSH or LH to affect these functions. Studies with hypophysectomized or PMSG-primed immature animals and in-vitro model systems have shown that exogenous FSH is as capable as LH in effecting maturation of the oocyte (Tsafriri, Lindner, Zor \& Lamprecht, 1972; Koch, Zor, Pomerantz, Chobsieng \& Lindner, 1973; Neal \& Baker, 1975; Hillensjo, 1976; Tsafriri et al., 1976), ovulation (Carter, Woods \& Simpson, 1961; Lostroh \& Johnson, 1966; Grimek, Nuti, Nuti \& McShan, 1976), luteinization (Channing, 1970a, b; Kolena \& Channing, 1972), and maintenance of luteal function (Greenwald, 1967, 1973). 
Our aim in the present study was to examine the requirement for endogenous FSH in each one of the above-listed events occurring during the periovulatory period in the hamster. The effect of neutralizing FSH on follicular maturation, as assessed by the ovulability of the follicles, was also studied.

\section{Materials and Methods}

\section{Animals}

Female golden hamsters (Mesocricetus auratus) of our Institute colony, 2-3 months of age, were housed in groups of 5-6 per cage and given pelleted food (Hindustan Levers Ltd, Bombay) and water ad libitum. The lighting schedule was adjusted to $14 \mathrm{~h}$ light $(06.00-20.00 \mathrm{~h})$ and $10 \mathrm{~h}$ darkness. The day of oestrus, corresponding to the time of ovulation, was recognized by the appearance of a thick odorous discharge of mucus from the vagina. The day on which spermatozoa were detected in the vaginal discharge of the mated animals was considered as Day 1 of pregnancy. Animals had to have exhibited at least two regular cycles before inclusion in any of the experiments.

\section{Antisera}

The antisera were produced in bonnet monkeys (Macaca radiata) by immunizing them with sheep pituitary FSH and LH (obtained as gifts from the NIAMDD National Pituitary Agency, NIH, Bethesda). The immunization and bleeding schedule was similar to that used for rabbits as described in detail elsewhere (Madhwa Raj \& Moudgal, 1970; Jagannadha Rao, Moudgal, Madhwa Raj, Lipner \& Greep, 1974a). Because it is important to characterize thoroughly an antiserum before use, the modifications adopted for rigorous characterization and the criteria of specificity are described in detail.

Removal of non-specific antibodies. The crude antisera to ovine FSH and LH contained antibodies directed against sheep serum and tissue protein which could be present as minute contaminants in the gonadotrophins used as immunogens. The removal of these was achieved by using an immunosorbent in the form of polymerized normal sheep serum, prepared according to a method standardized in our laboratory using ethyl chloroformate (B.D.H. Ltd, U.K.) as the polymerizing agent (Muralidhar, Samy \& Moudgal, 1974). After treatment with the polymer for 3-4 h, the crude antiserum was checked for the removal of non-specific antibodies in an Ouchterlony agar-gel doublediffusion test. The treatment was repeated until the absorption was complete.

Removal of LH antibody contamination from FSH antiserum. The LH antibody in the FSH antiserum was removed by adding an appropriate amount of $\mathrm{LH}$ to the antiserum. The amount was determined by incubating $5 \mu \mathrm{l}$ FSH antiserum for $4 \mathrm{~h}$ with graded doses of LH (NIH-LH-S18) ranging from 100 to $1000 \mathrm{ng}$ followed by a second incubation with ${ }^{125} \mathrm{I}$-labelled ovine $\mathrm{LH}$ at $37^{\circ} \mathrm{C}$ for $10-12 \mathrm{~h}$. The radioactivity in the precipitate formed by addition of the second antibody to monkey gamma globulin was determined and the percentage of labelled LH bound was calculated for each dose. From the amount of LH needed to inhibit completely the binding of labelled LH to the FSH antiserum, it was possible to calculate the amount required to remove LH antibody from any larger volume of FSH antiserum. The absorbed FSH antiserum was re-checked for its ability to bind ${ }^{125} \mathrm{I}-$ labelled ovine $\mathrm{LH}$.

Criteria of specificity of antisera. The specificity of the antisera and their cross-reactivity with hamster pituitary gonadotrophins were determined by immunological and biological tests.

(1) The immunological method used was essentially as described earlier (Madhwa Raj \& Moudgal, 1970; Jagannadha Rao et al., 1974a), except that organic solvents were used to separate free and bound radioactivity (Thomas, Nash \& Ferin, 1969). Briefly, the method consisted of radioiodinating highly purified ovine LH and FSH (kindly supplied by Professors H. Papkoff and C. H. Li, Hormone Research Laboratory, San Francisco, California) by the standard procedure using chloramine-T (Greenwood, Hunter \& Glover, 1963). Undiluted antiserum $(5 \mu \mathrm{l})$ was incubated with a known amount of ${ }^{125} \mathrm{I}$-labelled hormone at $37^{\circ} \mathrm{C}$ for $6-12 \mathrm{~h}$ before separation of bound and free hormone by the addition of isopropyl alcohol (AnalaR, B.D.H. Ltd, U.K.) to a final saturation of $50 \%$. After 
standing at room temperature $\left(27^{\circ} \mathrm{C}\right)$ for $15-20 \mathrm{~min}$, the precipitate was separated by centrifugation and counted for bound radioactivity in a Packard Autogamma spectrometer. The results were expressed as percentage of specific radioactivity bound by the antiserum. This method was found to be reliable, fast and reproducible.

The ability of FSH and LH antisera to bind gonadotrophins of a heterologous origin was checked using ${ }^{125}$ I-labelled rat FSH and rat LH (NIAMDD-rat-FSH-I3 and NIAMDD-rat-LH-I4).

(2) In the biological tests, the ability of the LH and FSH antisera to block ovulation induced by LH in PMSG-primed 25-day-old immature rats was used to determine the neutralizing ability of the L.H antiserum and to detect the presence of contaminating LH antibodies, if any, in the FSH antiserum.

Treatment of immature rats with hamster pituitary extract caused stimulation of $\left[{ }^{3} \mathrm{H}\right]$ thymidine incorporation into ovarian DNA in vitro. The ability of the FSH antiserum, freed of LH antibody, to abolish this stimulatory effect was taken as a criterion for the biological cross-reactivity of the antiserum with hamster FSH. Female rats, 25 days of age, from the Institute colony were randomly distributed into three groups and treated with $0.2 \mathrm{ml} 0.9 \% \mathrm{NaCl}, 0.2 \mathrm{ml}$ hamster pituitary extract in saline (i.e. the equivalent of half a pituitary from hamsters killed on the morning of pro-oestrus) or $0.2 \mathrm{ml}$ hamster pituitary extract $+0.1 \mathrm{ml}$ FSH antiserum. The animals were killed $18 \mathrm{~h}$ later. The ovaries were removed, coarsely minced and transferred to $10 \mathrm{ml}$ conical flasks containing $1 \mathrm{ml}$ Krebs-Ringer bicarbonate buffer, $\mathrm{pH} 7 \cdot 4$, containing $11.1 \mathrm{~mm}$-glucose and $50 \mathrm{~mm}$-Hepes (Sigma Chemical Co.) (Umbreit, Burris \& Stauffer, 1964). To each flask was added $1 \mu \mathrm{Ci}\left[{ }^{3} \mathrm{H}\right]$ thymidine (sp. act. $10 \cdot 5 \mathrm{Ci} / \mathrm{mmol}$ : B.A.R.C., Bombay) and the tissues were incubated at $37^{\circ} \mathrm{C}$ for $1 \mathrm{~h}$ in a Dubnoff metabolic shaker. After washing and homogenization, the macromolecules were precipitated by the addition of cold perchloric acid to a final concentration of $0.5 \mathrm{~N}$. The precipitate obtained after washing twice with $0.5 \mathrm{~N}$ perchloric acid was hydrolysed in $1 \mathrm{~N}$-perchloric acid at $90^{\circ} \mathrm{C}$ for $15-20 \mathrm{~min}$ and the radioactivity in the hydrolysate was determined by means of a Packard Tricarb liquidscintillation spectrometer using toluene/Triton-X100 (2:1 v/v). Burton's modified diphenylamine method (Giles \& Myers, 1965) was used to estimate the amount of DNA in the hydrolysate. The results were expressed as ct/min $\left[{ }^{3} \mathrm{H}\right]$ thymidine incorporated per $100 \mu \mathrm{g}$ DNA, and statistically evaluated using Student's $t$ test.

\section{Assay of progesterone}

Progesterone in the plasma or ovarian homogenates after extraction with diethyl ether $(\times 3)$ and reconstitution in $0.01 \mathrm{M}$-phosphate buffer, $\mathrm{pH} 7 \cdot 4$, containing $0.1 \%$ gelatin (Difco) was estimated by a radioimmunoassay essentially according to the method of Thorneycroft \& Stone (1972) using $\left[1,2,6,7-{ }^{3} \mathrm{H}\right]$ progesterone (sp.act. $80-100 \mathrm{Ci} / \mathrm{mmol}$ : New England Nuclear, Boston) which was repurified by t.1.c. in a system of chloroform: acetone $(9: 1 \mathrm{v} / \mathrm{v})$ and an antiserum to progesterone- $11 \alpha$ hemisuccinyl-BSA raised in our laboratory. This antiserum is specific to progesterone with very little cross-reactivity with $17 \alpha$-hydroxyprogesterone ( $2 \%$ ) and $20 \alpha$-hydroxyprogesterone $(7 \%)$. Nonradioactive progesterone (Sigma Chemical Co.) used for the standard curve was recrystallized before use. The free and bound labelled steroid were separated by dextran-charcoal treatment. This assay system has been validated (Mukku \& Moudgal, 1975; Mukku, 1976) to measure hamster plasma and ovarian progesterone with accuracy (coefficient of variation being $10 \%$ or less for concentrations higher than $1-2 \mathrm{ng} / \mathrm{ml}$ serum and 3-4\% for luteal concentrations), high precision (intraand inter-assay variations being $5 \%$ and $9 \%$ respectively) and sensitivity (25-50 pg).

\section{Results}

\section{Characterization of antisera}

Immunological criteria. Treatment of LH and FSH antisera with polymerized normal sheep serum removed all non-specific antibodies directed towards serum and tissue proteins as shown by the Ouchterlony agar-gel double-diffusion test. The results presented in Table 1 indicate the specificity 
Table 1. Binding of ${ }^{125}$ I-labelled hormones to antisera to ovine FSH and LH (mean \pm S.D. of 5 determinations)

\begin{tabular}{|c|c|c|c|c|}
\hline \multirow{2}{*}{$\begin{array}{l}\text { Antiserum } \\
\quad(5 \mu \mathrm{l})\end{array}$} & \multicolumn{4}{|c|}{$\%$ specific binding of hormone* } \\
\hline & Ovine LH & Rat LH & Ovine FSH & Rat FSH \\
\hline LH & $87 \cdot 3 \pm 2 \cdot 02$ & $58 \cdot 8 \pm 2 \cdot 12$ & $1.80 \pm 0.1$ & $30 \cdot 0 \pm 0.8$ \\
\hline $\begin{array}{l}\text { FSH } \\
\text { (unabsorbed) }\end{array}$ & $78 \cdot 0 \pm 6 \cdot 8$ & $55 \cdot 0 \pm 2 \cdot 7$ & $52.8 \pm 3.86$ & $59 \cdot 0 \pm 3 \cdot 5$ \\
\hline $\begin{array}{l}\text { FSH } \\
\text { (absorbed) }\end{array}$ & $2.0 \pm 0.04$ & $0.8 \pm 0.1$ & $53.8 \pm 4.06$ & $61 \cdot 8 \pm 5 \cdot 0$ \\
\hline
\end{tabular}

* The binding obtained after deduction of the corresponding nonspecific binding of each hormone to $5 \mu$ normal monkey serum.

of the antisera. While LH antiserum showed binding to both ovine and rat LH, it showed little binding to ovine FSH; the binding of LH antiserum to rat FSH might have been due to contamination with rat $\mathrm{LH}$ in the rat FSH preparation used for radioiodination.

Ovine FSH antiserum, in addition to binding FSH also showed considerable binding to ${ }^{125} \mathrm{I}-$ labelled ovine LH. Determination of the amount of LH added to inhibit the binding of ${ }^{125}$ I-labelled LH to $5 \mu \mathrm{l} \mathrm{FSH} \mathrm{antiserum} \mathrm{prevented} \mathrm{the} \mathrm{addition} \mathrm{of} \mathrm{an} \mathrm{undesired} \mathrm{excess} \mathrm{of} \mathrm{LH} \mathrm{to} \mathrm{the} \mathrm{antiserum} \mathrm{and,}$ as shown in Table 1, FSH antiserum absorbed with a minimal amount of LH showed virtually no binding to ${ }^{125} \mathrm{I}$-labelled ovine or rat $\mathrm{LH}$, while retaining almost completely the ability to bind labelled ovine and rat FSH.

Biological criteria. Treatment with LH antiserum was effective in blocking ovulation induced by LH in PMSG-primed immature rats. Although unabsorbed FSH antiserum also blocked ovulation, the same antiserum was no longer effective after absorption with $\mathrm{LH}$, thereby confirming the absence of LH antibody in the absorbed FSH antiserum.

When 21-day-old female rats were treated with hamster pituitary extract, the incorporation (ct/ min per $100 \mu \mathrm{g}$ DNA) of $\left[{ }^{3} \mathrm{H}\right]$ thymidine was increased $(7320 \pm 944$ (S.E.M.), $\mathrm{N}=3$ ) compared with $4310 \pm 901, N=3$, in saline-treated rats $(P<0.05)$. Administration of absorbed FSH antiserum plus hamster pituitary extract inhibited the stimulation $(4880 \pm 732, \mathrm{~N}=3)$, demonstrating the cross-reactivity with and the ability of ovine FSH antiserum to neutralize hamster FSH.

\section{Experiments}

Oocyte maturation and ovulation. At $13.00 \mathrm{~h}$ on the day of pro-oestrus cyclic hamsters were given $0.2 \mathrm{ml}$ normal monkey serum (NMS), $0.1 \mathrm{ml} \mathrm{FSH} \mathrm{antiserum} \mathrm{or} 0.2 \mathrm{ml} \mathrm{LH}$ antiserum by subcutaneous or intracardiac routes. At $09.00 \mathrm{~h}$ on the next day (oestrus), the animals were killed and their oviducts were examined for the presence of ova by gently pressing them between two glass slides and examining under a microscope. As shown in Table 2, FSH antiserum did not block the ovulation occurring on the next day, but LH antiserum did do so. To assess the quality of the ova shed, the animals were

Table 2. Effect of the administration of antisera to ovine FSH or LH on ovulation and implantation* in hamsters

\begin{tabular}{|c|c|c|c|}
\hline Treatment & $\begin{array}{c}\text { No. ovulating/ } \\
\text { no. treated }\end{array}$ & $\begin{array}{c}\text { Mean } \\
( \pm S . D .) \\
\text { no. of ova }\end{array}$ & $\begin{array}{c}\text { Mean }( \pm S . D .) \\
\text { no. of implantation } \\
\text { sites } \\
\text { on Day } 8\end{array}$ \\
\hline $\begin{array}{l}\text { Normal monkey } \\
\text { serum }\end{array}$ & $10 / 10$ & $10 \cdot 8 \pm 1 \cdot 4$ & $10 \pm 2$ \\
\hline FSH antiserum & $20 / 20$ & $10 \cdot 0 \pm 1.7$ & $10 \pm 2$ \\
\hline LH antiserum & $0 / 25$ & 0.0 & - \\
\hline
\end{tabular}

* In another group of similarly treated hamsters. 
Table 3. Effect of antisera to ovine FSH and LH on plasma progesterone concentrations (each value is the mean \pm S.E.M. of samples from 10 animals and estimated in two separate radioimmunoassays) in cyclic hamsters

\begin{tabular}{lccc}
\hline & \multicolumn{3}{c}{ Plasma progesterone (ng/ml) } \\
\cline { 2 - 4 } \multicolumn{1}{c}{ Treatment } & $\begin{array}{c}\text { Pro-oestrus } \\
(17.00 \mathrm{~h})\end{array}$ & $\begin{array}{c}\text { Oestrus } \\
(17.00 \mathrm{~h})\end{array}$ & $\begin{array}{c}\text { Dioestrus-1 } \\
(09.00 \mathrm{~h})\end{array}$ \\
\hline Normal monkey serum & $15.4 \pm 0.63$ & $8.25 \pm 1.4$ & $8.64 \pm 0.72$ \\
FSH antiserum & $16.4 \pm 1.76$ & $8.09 \pm 2.23$ & $8.73 \pm 2.73$ \\
LH antiserum & $1.66 \pm 0.25$ & $1.15 \pm 0.17$ & $1.08 \pm 0.25$ \\
\hline
\end{tabular}

placed with males of proven fertility; after confirming the presence of spermatozoa in the vaginal smear the next day, the animals were killed on Day 8 and the uteri were examined for the presence of normal implantation sites (Table 2). It was clear that even in the absence of endogenous FSH, oocyte maturation, fertilization and implantation had occurred normally.

Luteinization. Increased levels of progesterone in the circulation after the gonadotrophin surges on the evening of pro-oestrus (Lukaszewska \& Greenwald, 1970) were taken as the index of normal occurrence of the process of luteinization. At $13.00 \mathrm{~h}$ on the day of pro-oestrus hamsters were given an intracardiac injection of $0.2 \mathrm{ml} \mathrm{NMS,} 0.1 \mathrm{ml} \mathrm{FSH}$ antiserum or $0.2 \mathrm{ml} \mathrm{LH}$ antiserum. Blood (1 ml) was collected by cardiac puncture under ether anaesthesia at $17.00 \mathrm{~h}$ on the same day and at $17.00 \mathrm{~h}$ on the next day (i.e. oestrus). The animals were killed at $09.00 \mathrm{~h}$ on the first day of dioestrus and blood and ovaries were collected. Plasma was separated from the citrated blood and stored frozen until assayed for progesterone. The results indicated that although administration of FSH antiserum did not affect the progesterone concentration, LH antiserum completely prevented the increase in plasma progesterone (Table 3).

Maintenance of luteal function. The progesterone content of the isolated corpora lutea on Day 8

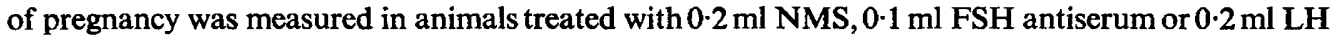
antiserum on Day 7 of pregnancy. In cyclic animals, the ovarian progesterone content on the first day of dioestrus, the day when progesterone levels are maximal during the cycle, was measured at $09.00 \mathrm{~h}$ after treatment with LH or FSH antiserum on the day of pro-oestrus at $13.00 \mathrm{~h}$. Treatment with FSH antiserum had no effect on luteal progesterone concentration in pregnant or cyclic hamsters, but LH antiserum caused a drastic reduction (Table 4).

Follicular maturation. The completion of the follicular maturation process was assessed by checking for ovulation at the end of the cycle, assuming that the number of ova shed is equal to the number of ovulable follicles. Neutralization of the pro-oestrous FSH surge by administering FSH antiserum $(0.1 \mathrm{ml})$ at $13.00 \mathrm{~h}$ resulted in a complete blockade of the ovulation expected to occur at the next oestrus, i.e. 5 days later (Table 5), suggesting an impairment in follicular development. However, since this result could also have arisen from an absence of the LH surge at the second pro-oestrus, the effect of administering an ovulatory dose of LH was tested. There was again no ovulation on the

Table 4. Effect of antisera to ovine FSH and LH on ovarian and luteal progesterone concentrations (mean \pm S.E.M.) in cyclic (10/group) and pregnant (5/group) hamsters

\begin{tabular}{|c|c|c|}
\hline \multirow[b]{2}{*}{ Treatment } & \multicolumn{2}{|c|}{ Progesterone (ng/mg) } \\
\hline & In $\mathrm{CL}^{*}$ & In ovary† \\
\hline Normal monkey serum & $33 \cdot 73 \pm 3 \cdot 1$ & $16.01 \pm 1.02$ \\
\hline FSH antiserum & $29 \cdot 96 \pm 1 \cdot 1$ & $18 \cdot 26 \pm 2 \cdot 00$ \\
\hline LH antiserum & $4.49 \pm 0.85$ & $3.82 \pm 1.06$ \\
\hline
\end{tabular}

* On Day 8 of pregnancy after treatment on Day 7.

+ On ist day of dioestrus after treatment on the day of prooestrus. 
Table 5. Effect of FSH antiserum at different times of the cycle on follicular maturation of hamsters

\begin{tabular}{lc}
\hline \multicolumn{1}{c}{$\begin{array}{c}\text { Treatment } \\
\text { with FSH antiserum }\end{array}$} & $\begin{array}{c}\text { No. of animals ovulating/ } \\
\text { no. treated }\end{array}$ \\
\hline Pro-oestrus $\left(13.00 \mathrm{~h}^{*}\right)$ & $0 / 40$ \\
Pro-oestrus $(13.00 \mathrm{~h} \dagger)$ & $0 / 10$ \\
Oestrus $(0.900 \mathrm{~h})$ & $0 / 5$ \\
Dioestrus-1 $(09.00 \mathrm{~h})$ & $0 / 5$ \\
Dioestrus-2 $(09.00 \mathrm{~h})$ & $0 / 5$ \\
Dioestrus-2 $(20.00 \mathrm{~h})$ & $0 / 8$ \\
Pro-oestrus $(09.00 \mathrm{~h} \ddagger)$ & $7 / 7$ \\
\hline
\end{tabular}

Control animals $(\mathrm{N}=10)$ given $0.1 \mathrm{ml}$ normal monkey serum at $13.00 \mathrm{~h}$ on pro-oestrus ovulated a mean $( \pm$ S.D.) of $11.0 \pm 1 \cdot 2$ ova when checked at $09.00 \mathrm{~h}$ on day of oestrus.

* Animals were killed, not on the next day, but at the second oestrus, 5 days later.

$\dagger$ These animals also received $50 \mu \mathrm{g} \mathrm{LH}$ on the next day of pro-oestrus, i.e. on the day before autopsy.

\$ These animals were killed on the next morning; a normal complement of ova $(10 \cdot 0 \pm 2 \cdot 2)$ was present.

next day. Histological examination of the ovaries of the antiserum-treated animals at autopsy showed an increase in the number of atretic follicles and the absence of any large follicles or freshly-formed corpora lutea (Moudgal \& Sheela Rani, 1975), thus confirming our contention that neutralization of the FSH surge leads to impairment of follicular maturation.

To study the effect on follicular growth of neutralizing endogenous FSH on other days of the cycle, a single s.c. injection of $0.1 \mathrm{ml}$ FSH antiserum was given on one of the other 4 days of the oestrous cycle and the animals killed at $09.00 \mathrm{~h}$ on the day of oestrus. Ovulation was completely blocked except on the morning of pro-oestrus (Table 5).

\section{Discussion}

Of the several periovulatory events examined in the present study for their dependency on endogenous FSH, oocyte maturation, ovulation, luteinization and maintenance of luteal function do not appear to be influenced by the neutralization of the pro-oestrous FSH surge. Such neutralization does, however, have an inhibitory effect on the process of follicular maturation. The former finding is quite contrary to the reports of several other workers who, using hypophysectomized animals or in-vitro systems, have shown that exogenous FSH is capable of bringing about most of these functions.

One of the early processes initiated by the preovulatory gonadotrophin surge is the resumption of meiotic division in the oocyte, which is usually arrested at birth in most species (Biggers \& Schuetz, 1972). Immunologically pure FSH has been shown to have an intrinsic ability to induce oocyte maturation in rat and mouse preovulatory follicles (Tsafriri et al., 1972, 1976; Neal \& Baker, 1975; Hillensjo, 1976). In these studies, changes in the oocyte such as germinal vesicle breakdown, disappearance of nucleolus, formation of meiotic spindle and elimination of the first polar body were considered as evidence for the resumption of the maturation process. However, the ultimate proof for the normality of the liberated oocyte lies in its ability to become fertilized and undergo embryonic development (Cross \& Brinster, 1970; Schuetz, 1974; Hillensjo, 1976). If this were our principal criterion, it could be concluded from the present study that oocyte maturation in its final stages is not dependent upon the FSH surge at pro-oestrus.

The requirement for FSH in ovulation has been a long-debated issue. While FSH has been shown to bring about ovulation in hypophysectomized, pentobarbital- or chlorpromazine-blocked rats and in PMSG-primed immature rats (Carter et al., 1961; Lostroh \& Johnson, 1966; Harrington, Bex, Elton \& Roach, 1970; Nuti, McShan \& Meyer, 1974; Tsafriri et al., 1976), endogenous FSH has not been found necessary for ovulation in any studies, including the present, in which FSH antiserum 
was used (Schwartz, Krone, Talley \& Ely, 1973; Moudgal, Rao, Maneckjee, Muralidhar, Mukku \& Sheela Rani, 1974; Jagannadha Rao et al., 1974a; Schwartz, Cobbs, Talley \& Ely, 1975). The role of LH in ovulation, on the other hand, has been unequivocally demonstrated in many systems (Kelly, Robertson \& Stanfield, 1963; Lostroh \& Johnson, 1966; Schwartz \& Gold, 1967; Sasamoto, 1969; Madhwa Raj \& Moudgal, 1970; Ely \& Schwartz, 1971; Moudgal, MacDonald \& Greep, 1971; Jagannadha Rao et al., 1974a; Lipner et al., 1974; Schwartz et al., 1975; Tsafriri et al., 1976). It is probable that in systems in which ovulation has been induced by FSH, it is due to synergism with the minimal amounts of LH that may be found in the system (either present in the system in low amounts, even after hypophysectomy, or as a contaminant), because FSH in combination with minimal amounts of LH has been shown to cause ovulation in hypophysectomized immature rats (Lipner et al., 1974).

Almost concomitant with the surge of gonadotrophins, a 'surge' of progesterone occurs on the day of pro-oestrus in hamsters (Lukaszewska \& Greenwald, 1970; Leavitt \& Blaha, 1970). Since this progesterone is also contributed by the preovulatory follicles (Blaha \& Leavitt, 1970), this increased secretion itself could be indicative of initiation of the luteinization process. In granulosa cell cultures, luteinization, as assessed by a number of criteria including the increase in progesterone secretion, has been induced by a variety of stimuli including FSH (Channing, 1970a, b; Kolena \& Channing, 1972). The results of the present study, however, clearly indicate that endogenous FSH is not required in this process, although $\mathrm{LH}$ is specifically needed.

When FSH antibodies are given in excess of the minimal effective dose at pro-oestrus, they persist in the circulation for the rest of that 4-day cycle, as indicated by the ability of the serum of the treated hamsters to bind ${ }^{125}$ I-labelled FSH (C. S. Sheela Rani \& N. R. Moudgal, unpublished data). Even with such continued neutralization of FSH, circulating and ovarian progesterone levels in the present study were not affected, giving rise to the conclusion that FSH is not required for the maintenance of luteal function in the cyclic hamster. It has been suggested by Greenwald $(1967,1973)$, based on his studies on hypophysectomized hamsters, that FSH with prolactin constitutes the minimal luteotrophic complex. Our results showing that neutralization of FSH has no effect on ovarian or luteal progesterone levels while treatment with $\mathrm{LH}$ antiserum causes drastic reduction are in accordance with those of our earlier studies on the relative involvement of FSH and LH in the maintenance of luteal function in the hamster (Jagannadha Rao, Madhwa Raj \& Moudgal, 1972; Mukku, Anand Kumar, Kamala Kumar, Rao \& Moudgal, 1974; Mukku \& Moudgal, 1975), and the differences cannot at present be explained.

The non-involvement of FSH in some of the periovulatory events discussed above led us to question the role of the FSH that is secreted as a surge at the same time as that of LH. Is it just coincidental (perhaps because they share a common releasing factor?) or does it have a functional significance? Earlier observations indicated that neutralization of FSH at pro-oestrus with an antiserum to FSH caused an arrest of cyclicity and reduction in ovarian and uterine weights, suggesting an impairment of follicular development and the importance of the FSH surge (Moudgal et al., 1974; Jagannadha Rao, Sheela Rani \& Moudgal, 1974b; Moudgal \& Sheela Rani, 1975). Similar suggestions have been made by other workers (Schwartz et al., 1973; Welschen, 1973; Greenwald, 1974; Moore \& Greenwald, 1974). In the present study, using FSH antiserum, it has been possible to show that neutralization of the surge of FSH at pro-oestrus affects the process of follicular growth and prevents the ovulation expected at the end of the next cycle. This effect could have been due to an interference with the increase in oestrogen that normally occurs on the 2nd day of dioestrus (Baranczuk \& Greenwald, 1973) and consequently of the preovulatory LH surge; but this possibility was excluded when exogenous LH given to the FSH antiserum-treated animals could not induce ovulation on the next day, confirming the absence of any large ovulable follicles.

The observed blockade of ovulation following FSH withdrawal at any stage of follicular growth clearly indicates the continued need for FSH throughout the growth of follicles, which is apparently completed by pro-oestrus. Once the follicles have 'matured' and reached the ovulable stage, they no longer seem to require FSH, but become dependent on LH for the subsequent ovulatory processes. This does not, however, preclude the possibility that LH is also required for the initiation and/or further development of follicles during that cycle. 
The work was supported generous grants from the Indian Council of Medical Research, New Delhi and the Ministry for Health and Family Planning, Government of India. One of us (C.S.S.) is grateful to the Council of Scientific and Industrial Research, India, for a Junior Research Fellowship.

\section{References}

Baranczuk, R. \& Greenwald, G.S. (1973) Peripheral levels of estrogen in the cyclic hamster. Endocrinology 92, 805-812.

Biggers, J.D. \& Schuerz, A.W. (Eds) (1972) Oogenesis. University Park Press, Baltimore.

Blaha, G.C. \& LeavitT, W.W. (1970) The distribution of ovarian $\Delta^{5}-3 \beta$-hydroxysteroid dehydrogenase activity in the golden hamster during the estrous cycle, pregnancy and lactation. Biol. Reprod. 3, 362368.

Carter, F., Woods, M.C. \& Simpson, M.E. (1961) The role of pituitary gonadotropins in induction of ovulation in the hypophysectomized rat. In Control of Ovulation, pp. 1-21. Ed. C.A. Villee. Pergamon Press, New York.

Channing, C.P. (1970a) Influences of the in vivo and in vitro hormonal environment upon luteinization of granulosa cells in tissue culture. Recent Prog. Horm. Res. 26, 589-622.

Channing, C.P. (1970b) Effects of stage of menstrual cycle and gonadotropins on luteinization of rhesus monkey granulosa cells in culture. Endocrinology 87, 49-60.

Cross, P.C. \& Brinster, R.L. (1970) In vitro development of mouse oocytes. Biol. Reprod. 3, 298-307.

Ely, C.A. \& Schwartz, N.B. (1971) Elucidation of the role of luteinizing hormone in estrogen secretion and ovulation by use of antigonadotropin serum. Endocrinology 89, 1103-1108.

Giles, K.W. \& MYers, A. (1965) An improved diphenylamine method for estimation of DNA. Nature, Lond. 206, 93-94.

Greenwald, G.S. (1967) Luteotropic complex of the hamster. Endocrinology 80, 118-130.

GrenNwald, G.S. (1973) Further evidence for a luteotropic complex in the hamster: progesterone determinations of plasma and corpora lutea. Endocrinology 92, 235-242.

GreENWALD, G.S. (1974) Gonadotropin regulation of follicular development in the hamster. In Gonadotropins and Gonadal Function, pp. 205-212. Ed. N.R. Moudgal. Academic Press, New York.

GreenwoOd, F.C., Hunter, W.M. \& Glover, J.S. (1963) The preparation of ${ }^{131}$ I-labelled human growth hormone with high specific radioactivity. Biochem. J. 89, 114-123.

GrimeK, H.J., Nutr, L.C., Nutt, K.M. \& MCShaN, W.H. (1976) Effect of neuraminidase treatment on the biological activity of highly purified ovine FSH and LH in hypophysectomized immature male and female rats. Endocrinology 98, 105-110.

Harrington, F.E., Bex, F.J., Elton, R.L. \& Roach, J.B. (1970) The ovulatory effect of follicle stimulating hormone treated with chymotrypsin in chlorpromazine-blocked rats. Acta enodcr., Copenh. 65, 222228.
Hillensjo, T. (1976) Oocyte maturation and glycolysis in isolated preovulatory. follicles of PMS-primed immature rats. Acta endocr., Copenh. 82, 809-830.

JaGannadHa RaO, A., MadHWa Raj; H.G. \& Moudgat; N.R. (1972) Effect of LH, FSH, and their antisera on gestation in the hamster. J. Reprod. Fert. 29, 239249.

JAGANNADHA RAO, A., Moudgal, N.R., MADHWA RAJ, H.G., LiPNeR, H. \& GreeP, R.O. (1974a) The role of FSH and $\mathrm{LH}$ in the initiation of ovulation in rats and hamsters: a study using rabbit antisera to ovine FSH and LH. J. Reprod. Fert. 37, 323-330.

JaGannadha Rao, A., Sheela Rani, C.S. \& Moudgal, N.R. (1974b) Studies on follicular maturationeffect of FSH and LH antisera in the hamster. In Gonadotropins and Gonadal Function, pp. 213-219. Ed. N.R. Moudgal. Academic Press, New York.

Kelly, N.A., Robertson, H.A. \& Stanfield, D.A. (1963) Suppression of ovulation in the rat by rabbit anti-ovine LH serum. $J$. Endocr. 27, 127-128.

Koch, Y., Zor, U., Pomerantz, S., Chobsieng, P. \& LINDNER, H.R. (1973) Intrinsic stimulatory action of FSH on ovarian adenylate cyclase. J. Endocr. 58, 677-678.

Kolena, J. \& Channing, C.P. (1972) Stimulatory effects of LH, FSH and prostaglandins upon cyclic AMP levels in porcine granulosa cells. Endocrinology 90, 1543-1550.

Leavitr, W.W. \& Blaha, G.C. (1970) Circulating progesterone levels in the golden hamster during the estrous cycle, pregnancy and lactation. Biol. Reprod. 3, 353-361.

LipNeR, H., Hirsch, M.A., Moudgal, N.R., MACDonald, G.J., YING, S.Y. \& GREEP, R.O. (1974) Ovulation-inducing activity of FSH in the rat. Endocrinology 94, 1351-1358.

LostroH, A.J. \& Johnson, R.E. (1966) Amounts of interstitial cell-stimulating hormone and follicle stimulating hormone required for follicular development, uterine growth and ovulation in the hypophysectomized rat. Endocrinology 79, 991-996.

LuKaszewsKa, J.H. \& GreENWALD, G.S. (1970) Progesterone levels in the cyclic and pregnant hamster. Endocrinology 86, 1-9.

Madhwa Raj, H.G. \& Moudgal, N.R. (1970) Hormonal control of gestation in the intact rat. Endocrinology 86, 874-889.

Moore, P.J. \& Greenwald, G.S. (1974) Effect of hypophysectomy and gonadotropin treatment in follicular development and ovulation in the hamster. Am. J. Anat. 139, 37-48.

Moudgal, N.R. \& Sheela Rani, C.S. (1975) Role of follicle stimulating hormone in ovarian follicular maturation. In Regulation of Growth and Differentiated Function in Eukaryote Cells, pp. 431-437. Ed. G.P. Talwar. Raven Press, New York. 
Moudgal, N.R., MacDonald, G.J. \& Greep, R.O. (1971) Effect of hCG antiserum on ovulation and corpus luteum formation in the monkey (Macaca fascicularis). J. clin. Endocr. Metab. 32, 579-581.

Moudgal, N.R., Jagannadha Rao, A., ManeckJet, R., Muralidhar, K., Mukku, V. \& Sheela Rani, C.S. (1974) Gonadotropins and their antibodies. Recent Prog. Horm. Res. 30, 47-77.

MUKKU, V. (1976) Regulation of icorpus luteum function. A: study using pregnant hamsters. Ph.D. thesis, Indian Institute of Science, Bangalore.

MukKu, V. \& Moudgal, N.R. (1975) Studies on luteolysis: effect of antiserum to luteinizing hormone: on sterols and steroid levels in pregnant hamsters. Endocrinology 97, 1455-1459.

Mukku, V., Anand Kumar, T.C., Kamala Kumar, JaganNadHa RaO, A. \& Moudgal, N.R. (1974) Ultrastructural changes in the corpus luteum of pregnancy in the golden hamster following LH deprival. In Gonadotropins and Gonadal Function, pp. 281-291. Ed. N.R. Moudgal. Academic Press, New York.

Muralidhar, K., Samy, T.S.A. \& Moudgal, N.R. (1974) Immunosorbents of gonadotropins and their antibodies. In Gonadotropins and Gonadal Function, pp. 169-184. Ed. N.R. Moudgal. Academic Press, New York.

Neal, P. \& Baker, T.G. (1975) Response of mouse Graafian follicles in organ culture to varying doses of LH and FSH. J. Endocr. 65, 27-32.

Nuti, L.C., MCShan, W.H. \& Meyer, R.K. (1974) Effect of ovine FSH and LH on serum steroids and ovulation in hypophysectomized immature female rats. Endocrinology 95, 682-689.

SASAMOTO, S. (1969) Inhibition of hCG-induced ovulation by anti-HCG serum in immature mice pretreated with PMSG. J. Reprod. Fert. 20, 271-277.

SchueTz, A.W. (1974) Role of hormones in oocyte maturation. Biol. Reprod. 10, 150-178.
SchWARTz, N.B. \& Gold, J.J. (1967) Effect of a single dose of anti-LH serum at proestrus on the rat estrous cycle. Anat. Rec. 157, 137-150.

Schwartz, N.B., Krone, K., Talley, W.L. \& Ely, C.A. (1973) Administration of antiserum to ovine FSH in the female rats failure to influence immediate events of the cycle. Endocrinology 92, $1165-1174$.

Schwartz; N.B., CobBs; S.B., TAlley, W.L. \& Ely, C.A. (1975) Induction of ovulation by LH and FSH in the presence of: antigonadotropic sera. Endocrinology 96, 1171-1178.

Thomas, K., NASh, D. \& Ferin, J. (1969) Chemical precipitation techniques for the radioimmunologioal quantitation of gonadotropins with special reference to the organic solvent dioxane. Acta endocr., Copenh., Suppl. 142, 279-299.

ThORNEYCRofT, I.H. \& StONE, S.C. (1972) Radioimmunoassay of serum progesterone in women receiving oral contraceptive steroids. Contraception 5, 129-146.

TSAFriRI, A., LinDNeR, H.R., ZoR, U. \& LAMPREChT, S.A. (1972) Induction of in vitro meiotic division in follicle-encircled rat oocytes by LH, cyclic AMP and prostaglandin $\mathrm{E}_{2}$.J. Reprod. Fert. 31, 39-50.

TSAFriri, A., Lieberman, M.E., КосH, Y., Bauminger, S., ChOBsieng, P., ZoR, U. \& LindNer, H.R. (1976) Capacity of immunologically purified FSH to stimulate cyclic AMP accumulation and steroidogenesis in Graafian follicles and to induce ovum maturation and ovulation in the rat. Endocrinology 98, 655-661.

UMBREIT, W.W., BURRIS, R.H. \& STAUFFER, J.F. (1964) Manometric Techniques, 2nd edn. Burgess, Minneapolis.

WeLSCHEN, R. (1973) Amounts of gonadotropins required for normal follicular growth in hypophysectomized adult rats. Acta. endocr., Copenh. 72, $137-155$. 